С. В. Очеретенко, Д. С. Огульчанська

Харківський національний автомобільно-дорожній університет, Харків, Україна

\title{
ПІДВИЩЕННЯ ЕФЕКТИВНОСТІ СВІТЛОФОРНОГО РЕГУЛЮВАННЯ НА ПЕРЕХРЕСТІ
}

\begin{abstract}
Анотація. Розглядаються заходи, які спрямовані на підвищення ефективності функціонування регульованого перехрестя. Розглянути середні затримки транспортних засобів на нерегульованому та регульованому перехрестях. Встановлені моделі, що дозволяють визначити середні затримки транспортних засобів на перехресті в залежності від інтенсивності транспортного потоку по другорядній вулиці та тривалості основного такту. Критерієм вибору тривалості основних тактів світлофорного регулювання прийнято мінімум середніх затримок на перехресті.
\end{abstract}

Ключов і слов а: регульоване перехрестя, транспортний потік, транспортний засіб, детектор транспорту, затримка транспортних засобів, світлофорний цикл.

\section{Вступ}

Проведений аналіз зміни рівня автомобілізації в містах України за останні десять років показав, що рівень автомобілізації продовжує зростати. Дана обставина викликає збільшення інтенсивності транспортних потоків на транспортних магістралях, що в свою чергу викликає збільшення навантаження на вулично-дорожню транспортну мережу.

У великих містах автомобілі більшу частину часу перебувають в умовах світлофорного регулювання. Тому ефективне управління світлофорами $є$ необхідною умовою для вирішення проблеми транспортних заторів.

Вулично-дорожня мережа за тривалий період не зазнає реконструкції. У зв'язку з цим швидкість руху транспортних засобів по місту значно зменшується. Як відомо [1-5] найбільші проблеми з рухом і найбільші затримки транспортних засобів спостерігаються на перехрестях. Організовувати рух на перехрестях можливо, як за допомогою знаків, дорожньої розмітки, так і за допомогою дорожнього обладнання (світлофорів). Найбільш поширений спосіб світлофорного регулювання - використання фіксованих по тривалості фаз, розрахованих на основі статистичних даних. Однак в сучасних умовах динаміка потоків змінюється значно протягом доби.

На перехрестях, на яких організація проїзду здійснюється за допомогою дорожніх знаків, основні затримки виникають у транспортних засобів, які їдуть по другорядній дорозі. Збільшення інтенсивності руху по другорядній дорозі викликає збільшення сумарних затримок на перехресті.

Коли інтенсивність руху автомобілів по другорядній дорозі збільшується, і регулювання за допомогою знаків, і розмітки не забезпечує безпеку руху, то для регулювання руху використовують світлофорну сигналізацію. У цьому випадку потрібно визначити таки параметри світлофорного циклу, щоб затримки транспортних засобів на перехресті були мінімальні [3, 5-7].

Однією з сучасних тенденцій управління дорожнього руху на регульованих перехрестях є застосування адаптивного управління. Для впровадження даного виду управління необхідно використання різних видів датчиків, які визначають різні параметри руху автомобілів по дорогах.

Відповідно, одним з актуальних питань при оптимізації дорожнього руху на перехрестях $\epsilon$ визначення параметрів світлофорного циклу і їх зміни при використанні сучасних датчиків. Так одним 3 різновидів датчиків $є$ датчик «присутності» автомобіля в зоні перехрестя. Даний датчик дає команду дорожньому контролеру про присутність автомобіля на дорозі і необхідність перемикання сигналів світлофора. Ефективність світлофорного регулювання на таких перехрестях залежить від параметрів світлофорного циклу. Таким чином, для визначення оптимальних параметрів світлофорного циклу необхідно провести аналіз затримок транспортних засобів на перехресті до введення і після введення світлофорного регулювання 3 використанням сучасних датчиків.

\section{Аналіз публікацій}

Питаннями визначення основних параметрів світлофорного циклу займалося багато вітчизняних і зарубіжних авторів. Одним з перших авторів, який присвятив роботу оптимізації світлофорного циклу $\epsilon$ Вебстер. Так само докладно цим питанням приділяли увагу такі автори як Городілін, Дащенко, Усов, Врубель, Ахамандінов М.М, Заваліщін Д.С. [3-5].

Сельянов [8] стверджує, що ефективність використання сигналів світлофорів залежить від двох показників:

- частка сигналу що дозволяє рух від загальної тривалості;

- інтенсивність руху.

Так само велике значення має вибір тривалості циклу.

Так автор Городілін [9] говорить, що тривалість основного такту світлофорного об'єкта визначається завданням, яке ставиться перед дослідником: забезпечити певний напрям руху необхідним відрізком часу для виїзду на перетин проїжджої частини всіх транспортних засобів, що під'їхали до перехрестя за час циклу. Час, необхідний конкретному останньому транспортному засобу, що під'їхав до перехрестя, для отримання права в'їзду на перехрестя, безпосередньо залежить від відстані, яку він по- 
винен подолати 3 моменту відновлення руху на сигнал світлофора, що дозволяє рух до моменту включення заборонного (жовтого) сигналу.

Місце розташування останнього в черзі автомобіля від стоп-лінії ( $S_{i}$ в'їзду) визначається за формулою

$$
S_{i}=n_{i} \cdot(B+l),
$$

де $n_{i}-$ кількість автомобілів на одній смузі руху, що під'їхали до перехрестя за час одного циклу роботи світлофорного об'єкта, од.; $B$ - середня довжина легкового автомобіля (в розрахунках можна приймати рівною 4,5 м); $l$ - середня дистанція між автомобілями, що стоять перед перехрестям на заборонений сигнал світлофора (в розрахунках може прийматися рівною $1 \mathrm{M}$ ).

Кількість автомобілів на одній смузі руху, що під'їхали до перехрестя можна визначити за формулою

$$
n_{i}=\frac{N_{a}^{i}}{c},
$$

де $N_{a}^{i}$ - інтенсивність транспортного потоку досліджуваного напрямку за час циклу, од./120 c; $c$ - кількість смуг проїзної частини, призначених для руху в даному напрямку, од.

3 урахуванням темпу розгону і затримки перед початком руху $i$-й в черзі на конкретній смузі автомобіль досягне місця, що дає йому право на продовження руху через перехрестя через $t_{\mathrm{o} i}(\mathrm{c})$, яке за змістом збігається 3 тривалістю основного такту, пропонується визначати за формулою

$$
t_{0 i}=\sqrt{\frac{2 \cdot\left(S_{i}-S_{\mathrm{Oч}}\right)}{a}}+t_{\text {затр }},
$$

де $\left(S_{i}-S_{\text {оч }}\right)$ - відстань, яку долає автомобіль, що знаходився останнім в черзі, з моменту початку руху на сигнал світлофора що дозволяє рух до моменту досягнення границі, починаючи 3 якого водій не буде мати у своєму розпорядженні технічну можливість зупинити транспортний засіб до місця, встановленого Правилами дорожнього руху (стоп-лінія, пішохідний перехід, межа проїжджої частини). В даному випадку таким місцем слід вважати стоплінію), м; $S_{\text {очi }}$ - дальність розташування транспортного засобу щодо границі, регламентованої Правилами дорожнього руху, після досягнення якої водій транспортного засобу не має технічну можливість зупинитися і отримує право продовжити рух через перехрестя, м; $a$ - прискорення автомобіля, м/ $\mathrm{c}^{2}$ (для практичних розрахунків приймається $\left.1,5 \mathrm{M} / \mathrm{c}^{2}\right) ; t_{\text {затр }}$ час затримки початку руху останнього в черзі автомобіля, с.

Загальний час затримки пропонується визначати за формулою

$$
t_{\text {затр }}=n_{i} \cdot t_{\text {затр.ср }},
$$

де $t_{\text {затр.сp }}$ - середня тривалість часу затримки початку руху кожного автомобіля, що знаходиться в черзі, с (в розрахунках ви користується 1,0 с);

$$
S_{\mathrm{O \Psi}}=\left(t_{1}+t_{2}+0,5 t_{3}\right) \frac{V_{a}}{3,6}+\frac{V_{a}^{2}}{26 J_{\text {Ж }}},
$$

де $V_{a}$ - найбільш ймовірна швидкість останнього в черзі транспортного засобу, досягнута їм до моменту включення заборонного сигналу світлофора, км/год (для практичних розрахунків приймається 40 км/год); Јж - середне уповільнення транспортного засобу при включенні заборонного (жовтого) сигналу, м/ $\mathrm{c}^{2}$ (для сухого асфальтового покриття в практичних розрахунках приймається $\left.4,6 \mathrm{M} / \mathrm{c}^{2}\right) ; t_{1}-$ час реакції водія транспортного засобу в дорожньо-транспортній ситуації, що склалася, с (для практичних розрахунків приймається 0,6 c); $t_{2}$ - час запізнювання спрацьовування гальмівного приводу транспортного засобу, с (для практичних розрахунків приймається $0,1 \mathrm{c}$ ); $t_{3}-$ час наростання уповільнення транспортного засобу в даних дорожніх умовах, с (для практичних розрахунків приймається 0,35 c).

Таким чином, тривалість часу, необхідна для в'їзду на перехрестя останнього в черзі автомобіля, буде визначати час основного такту відповідного напряму, що дозволяє забезпечити беззаторний проїзд через перехрестя під'їхавших до нього транспортних засобів, 3 урахуванням його конфігурації і кількості смуг, призначених для руху в даному напрямку.

\section{Суть пропозиції}

Вибір тривалості основних тактів світлофорного циклу має великий вплив на ефективність його роботи. Занадто мала тривалість основних тактів призводить до зниження пропускної спроможності перехрестя, а велика тривалість основних тактів призводить до збільшення транспортних витрат часу. Для визначення оптимальних значень основних тактів необхідно знати закономірності формування потоку автомобілів на підході до світлофору.

Для формування бази даних необхідно провести обстеження.

В якості об'єкту дослідження обрано Т-подібне перехрестя. Основні напрямки руху представлені на рис. 1.

Головною дорогою є дорога в напрямку 1-2, напрямок 3 є другорядною дорогою (рис. 1).

При використанні датчиків присутності на другорядній дорозі організувати управління дорожнім рухом на даному типі перехрестя можна наступним чином:

- якщо на другорядній дорозі немає автотранспортних засобів, то рух по головній дорозі в напрямку 1 - 2, 2 - 1 здійснюється безперервно;

- якщо по другорядній дорозі з'являється транспортний засіб і під'їжджає в зону присутності, тоді сигнал світлофора що дозволяє рух включається по другорядній дорозі на певній проміжок часу.

При відсутності датчиків руху і світлофорного регулювання, коли проїзд регулюється за допомогою дорожніх знаків, то основні затримки транспортних засобів виникають на другорядній дорозі, а при великих значеннях інтенсивності по головній дорозі виїзд з другорядної дуже ускладнений. 


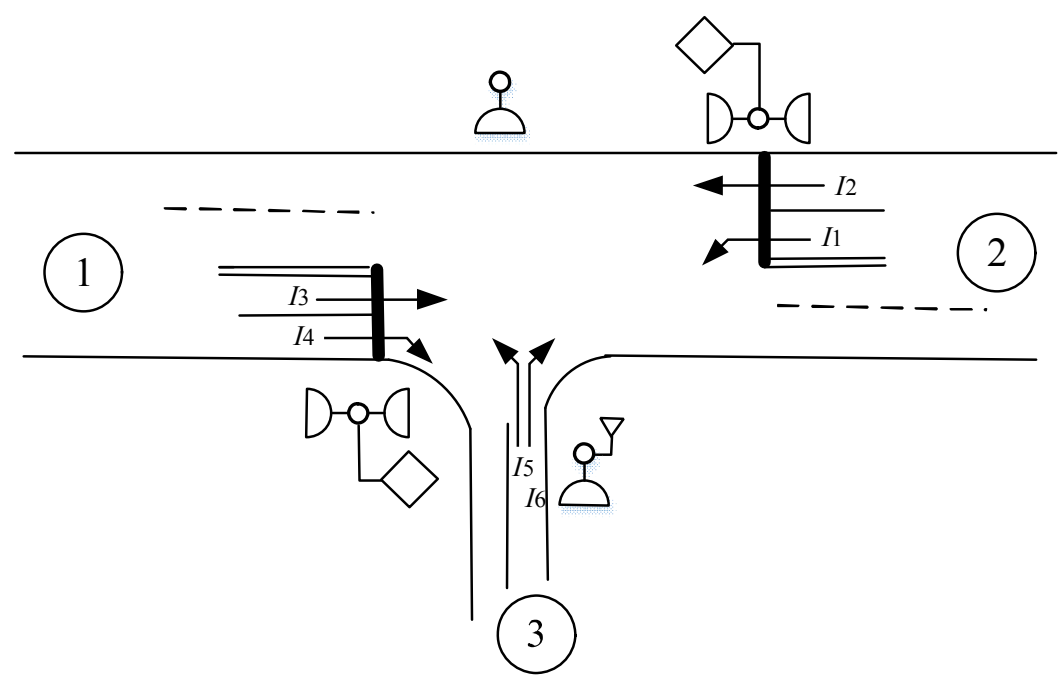

Рис. 1. Організація руху на перехресті

У зв'язку з цією обставиною доцільно впроваджувати на перетині адаптивне світлофорне регулювання.

Коли вводиться світлофорне управління на перехресті, проїзд перехрестя 3 другорядної дороги значно поліпшується. В цьому випадку затримки транспортних засобів на другорядній дорозі значно зменшуються, але в той же час виникають затримки на головній дорозі.

Поліпшення руху по другорядній дорозі може привести до збільшення інтенсивності руху по другорядній дорозі.

У цьому випадку можливі наступні ситуації:

- інтенсивність по другорядній дорозі низка i перемикання світлофорів відбувається при під'їзді автомобілів;

- інтенсивність транспортного потоку на другорядній дорозі велика і утворюється черга, що викликає постійне перемикання сигналів світлофора i зупинку основного транспортного потоку по головній дорозі, що викликає збільшення затримок на перехресті.

Отже, необхідно визначити такі параметри світлофорного регулювання, щоб при заданих значеннях основних тактів сумарні затримки на перехресті були мінімальні.

Тривалість світлофорного циклу повинна бути визначена за умови мінімум черг і часу затримки транспортних засобів в усіх напрямках.

Загальну аналітичну модель для визначення затримок на регульованому перехресті представимо в наступному вигляді

$$
t_{\Delta p}=\frac{\sum_{i=1}^{k} N_{j} \cdot t_{\Delta p j}}{\sum_{i=1}^{k} N_{j}},
$$

де $N_{j}$ - інтенсивність транспортних засобів для $j$-го потоку, од./год.

$t_{\Delta p j}-$ середній час затримки транспортних засобів на перехресті для ј-го потоку, с.

$k$ - кількість напрямків руху, од.
Середній час затримки транспортних засобів на регульованому перехресті визначаємо за такою формулою:

$$
\begin{gathered}
t_{\Delta p}= \\
=0,9\left[\frac{T_{\amalg} \cdot\left(1-\lambda_{i}\right)^{2}}{2 \cdot\left(1-\lambda_{i} \cdot x\right)}+\frac{x^{2}}{2 \cdot N_{i j} \cdot\left(1-x_{i j}\right)}\right],
\end{gathered}
$$

де $T_{u}$ - тривалість циклу регулювання, с;

$\lambda$ - відношення тривалості сигналу, що дозволяє рух, до тривалості циклу;

$x$ - ступінь насичення напрямку руху;

$N$ - інтенсивність руху Т3, од./год.

Розрахунок затримок на перехресті при відсутності світлофорного регулювання визначають за формулою

$$
\begin{gathered}
t_{\Delta t}=\frac{e^{N_{\mathrm{r}} t_{\mathrm{r}}}-N_{\mathrm{r}} t_{\mathrm{rp}}-1}{N_{\mathrm{r}}-N_{\mathrm{B}}\left(e^{N_{\mathrm{r}} t_{\mathrm{r}}}-N_{\mathrm{r}} t_{\mathrm{rp}}-1\right)}+ \\
+\frac{v_{a}}{7,2}\left(\frac{1}{a_{\mathrm{r}}}+\frac{1}{a_{\mathrm{p}}}\right),
\end{gathered},
$$

де $\quad e$ - підстава натурального логарифма;

$N_{2}$ - інтенсивність транспортного потоку на головній дорозі в обох напрямках, авт / с;

$N_{6}$ - інтенсивність, яка припадає в середньому на одну смугу другорядної дороги в цьому напрямку руху, авт / c;

$a_{m}$ i $a_{p}$ - відповідно уповільнення і прискорення автомобіля (в розрахунках можна прийняти

$$
\left.a_{m}=3-4 \mathrm{M} / \mathrm{c}^{2} ; a_{p}=1,0-1,5 \mathrm{M} / \mathrm{c}^{2}\right) ;
$$

$v_{a}$ - швидкість автомобіля в вільних умовах, км/год.

На досліджуваному перехресті проведено обстеження інтенсивності транспортних потоків. Обстеження проводилося в робочий день 3 9:00 до 11:00, з 13:00 до 15:00, з 18:00 до 20:00.

В результаті проведеного обстеження визначені інтенсивності руху транспортного потоку. Отримані значення представлені в табл. 1. 
Таблиця 1 - Інтенсивність руху

\begin{tabular}{|l|c|c|c|c|c|c|}
\hline Потік & $\boldsymbol{I}_{\mathbf{1}}$ & $\boldsymbol{I}_{\mathbf{2}}$ & $\boldsymbol{I}_{\mathbf{3}}$ & $\boldsymbol{I}_{\mathbf{4}}$ & $\boldsymbol{I}_{\mathbf{5}}$ & $\boldsymbol{I}_{\mathbf{6}}$ \\
\hline Інтенсивність, п.о. / год. & 4 & 1662 & 990 & 438 & 384 & 16 \\
\hline
\end{tabular}

На основі отриманих даних про інтенсивність транспортних потоків зроблено розрахунок затримок на даному перехресті за формулою (8). На основі отриманих даних проведено моделювання зміни загальних середніх затримок в залежності від різних значень інтенсивності по головній $N$ г і другорядній дорозі Nв. Отримані залежності представлені на рис. 2.

Отже, видно, що при існуючих значеннях інтенсивності по головній і другорядній дорозі значення затримок великі, тому введення світлофорної сигналізації є доцільним.

Для порівняння затримок транспортних засобів на перехресті зробимо розрахунок їх після впровадження світлофорного циклу.

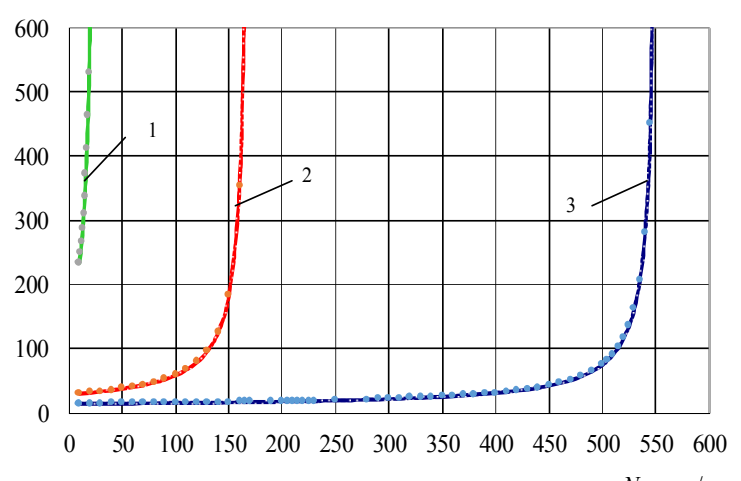

Рис. 2. Зміна середньої затримки транспортних засобів на нерегульованому перехресті в залежності від інтенсивності руху по другорядній дорозі:

1 - інтенсивності по головній дорозі 2000 авт./год,

2 - інтенсивності по головній дорозі 1000 авт./год,

3 - інтенсивності по головній дорозі 500 авт./год.

Для визначення ефективності роботи світлофорного циклу та отримання значення існуючих затримок на перехресті проведено обстеження тривалості основних тактів. В результаті натурного обстеження встановлено, що в ранкові години «пік» при відсутності розриву в транспортному потоці по другорядній дорозі час червоного сигналу для головної дороги становить 31 с, а червоний сигнал для другорядної дороги становить 47 с. Час світлофорного циклу становить 82 с. При ситуації, коли існує розрив в транспортному потоці по другорядній дорозі, червоний сигнал для головної дороги становить 31 с, а сигнал що забороняє рух для другорядної дороги змінюється від мінімального значення основного такту - 47 с до моменту під'їзду автотранспортного засобу.

Проведемо розрахунок існуючих затримок автотранспортних засобів на перехресті за умови, що час основного такту, який дозволяє рух для головної дороги, становить 47 с, а для другорядної 31 с. Розрахунок проведемо за формулою $(6,7)$. На основі отриманих розрахунків середня затримка автотранспортних засобів для перехрестя склала

$$
t_{\Delta p}=12,375 \mathrm{c} .
$$

У вечірній час при відсутності розриву транспортного потоку значення основного такту що дозволяє рух для головного напрямку відповідає $t_{\text {гл }}=$ $60 \mathrm{c}$, для другорядного напрямку $-t_{\text {др }}=18 \mathrm{c}$.

Визначимо затримки транспортного потоку для даних значень світлофорного циклу за формулами (6-7). В результаті проведених розрахунків встановлено, що значення затримки відповідає

$$
t_{\Delta p}=7,733 \mathrm{c} .
$$

Таким чином, видно, що затримки змінюються.

Проведено порівняльний аналіз тривалості світлофорного циклу і основних тактів. Встановлено, що в ранковий і вечірній час тривалість циклу однакова, але тривалість такту для другорядної дороги збільшена, а для основного транспортного потоку тривалість основного такту зменшена.

Для оцінки ефективності світлофорного циклу зробимо розрахунок зміни середніх затримок на перехресті при зміні тривалості основних тактів, а також при зміні інтенсивності транспортного потоку по другорядній дорозі.

В якості альтернативного способу зміни параметрів світлофорного циклу пропонується змінювати тривалість фази для другорядної дороги відповідно до інтенсивності, а тривалість фази для основного потоку не змінювати. Відповідно до запропонованої методики зроблено розрахунок середніх затримок на перехресті за формулами (6-7). Отримані результати представлені на рис. 3 .

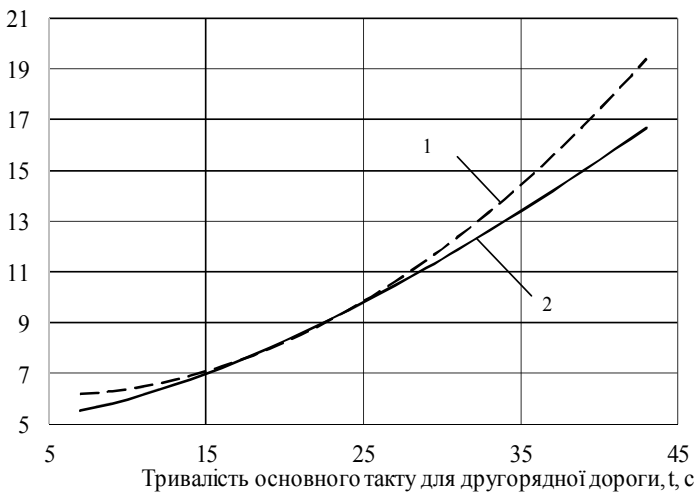

Рис. 3. Зміна середніх затримок на перехресті в залежності від тривалості основного такту для другорядній дорозі: 1 - існуюча система; 2 - пропонована методика.

Аналіз рис. 3 показує, що найменші затримки будуть спостерігатися, якщо використовувати пропоновану методику. 
Проведемо розрахунок зміни середніх затримок на перехресті при зміні тривалості основних тактів для другорядного напрямку, а також при зміні інтенсивності транспортного потоку по другорядній дорозі для розглянутих методик. Отримані результати представимо на рис. 4. Аналіз моделей показав, що найменші витрати часу спостерігаються при використанні пропонованого способу зміни тривалості основного такту для другорядної дороги.

\section{Висновки}

Аналіз отриманих результатів дозволив зробити висновок, що використання запропонованої методики по зміні тривалості основного такту для другорядної дороги забезпечує найменші затримки транспортних засобів на перехресті при різних значеннях інтенсивності руху. Таким чином, використання даної методики є доцільним.

Отримані залежності дозволяють оцінити на скільки середні затримки транспортних засобів на перехресті будуть менше, якщо використовувати запропоновану методику, в порівнянні 3 існуючою системою управління.

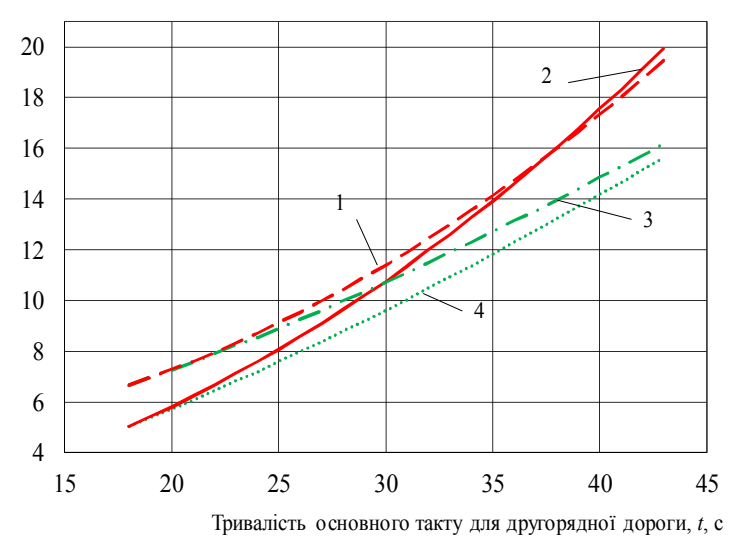

Рис. 4. Зміна середніх затримок на перехресті в залежності від тривалості основного такту на другорядній дорозі: 1 - при інтенсивності другорядній дорозі 300 авт/год за існуючою методикою;

2 - при інтенсивності другорядній дорозі 100 авт/год за існуючою методикою;

3 - при інтенсивності другорядній дорозі 300 авт/год за пропонованою методикою; 4 - при інтенсивності другорядній дорозі 100 авт/год за пропонованою методикою.

\section{СПИСОК ЛІТЕРАТУРИ}

1. Клинковштейн Г.И. Организация дорожного движения / Г.И. Клинковштейн - М.: Транспорт, 1981. -240 с.

2. Уджуху А.З. Применение методик расчета транспортных задержек на практике / Уджуху А.З., Лабутин // Вестник Донецкой академии автомобильного транспорта. - №3, 2018. - 34-40 с.

3. Григоров М.А Проблемы моделирования и управления движением транспортных потоков в крупных городах: монография / М.А. Григоров, А.Ф. Дащенко, А.В. Усов - Одесса: Астропринт, 2004. - 272 с.

4. Врубель Ю.А. Организация дорожного движения: В двух частях. Часть 2 / Ю.А. Врубель Минск: Белорусский фонд безопасности дорожного движения, 1996. - $306 \mathrm{c.}$

5. Ахамандинов М.М. Математеские модели управления транспортными потоками: монография / М.М. Ахамандинов, Д.С. Завалищин, Г.А. Тимофеева - Екатеренбург: УрГУПС, 2011. - 120 с.

6. Кременец Ю.А. Технические средства организации дорожного движения / Ю.А. Кременец, М.П. Печерский, М.Б. Афанасьев - М.: ИКЦ «Академкнига», 2005. - 279 с.

7. Кременец Ю.А. Технические средства организации дорожного движения / Ю.А. Кременец, М.П. Печерский, М.Б. Афанасьев. - Москва: Академкнига, 2005. - 279

8. Сильянов В.В. Теория транспортных потоков в проектировании дорог и организации движения. / В.В. Сильянов. М.: Транспорт, 1977. - 303 с.

9. Городокин В.А. Оптимизация работы светофорного объекта по основным тактам цикла // В.А. Городокин, З.В. Альметова, О.В. Леонова. - Транспорт. Транспортные сооружения. Экология № 4, 2015. - С. 67 - 76.

Received (Надійшла) 02.03.2020

Accepted for publication (Прийнята до друку) 22.04.2020

\section{Increasing the efficiency of lighting regulation on crossings}

S. Ocheretenko, D. Ohulchanska

Abstract. The subject of the study is the change in the average delays of vehicles at regulated intersections with adaptive control when using sensors "presence". The goal is to develop a method by which it is possible to determine the parameters of the traffic light cycle that provide the greatest efficiency of the traffic light object by reducing the average delays at the intersection. Research objectives: analysis of existing methods for determining the parameters of the traffic light cycle - the duration of the traffic light cycle and its main measures; determination of the dependence of changes in the average delay of vehicles at an unregulated intersection depending on the intensity of traffic on a secondary road; determination of the dependence of changes in average delays at the intersection depending on the duration of the main cycle for a secondary road at various values of intensity with adaptive control. The following results are received. Dependencies are obtained that make it possible to determine the changes in the average delays at the intersection from the duration of the main cycle for a secondary road with existing parameters and proposed parameters determined by the proposed methodology. The dependences of the change in the average delays at the intersection with a change in the duration of the main cycle for the secondary direction, as well as when the intensity of the traffic flow along the secondary road both with existing parameters and those proposed are obtained. Conclusions. The question of minimizing the delays of vehicles at intersections directly affects the efficiency of the transport network. Therefore, it is necessary to look for different options to reduce the average delays at intersections. One way is the use of adaptive control and the use of sensors "presence". Using the proposed methodology and the obtained models, it is possible to determine the duration of the main cycle in the traffic light cycle for a secondary road. This will minimize the average delays at the intersection, which in turn will increase the efficiency of its functioning.

Keywords : regulated intersection, traffic flow, vehicle, transport detector, delay of vehicles, traffic light cycle. 